\title{
GEORGE OF TREBIZOND'S VIEWS ON ISLAM AND THEIR ESCHATOLOGICAL BACKGROUNDS ${ }^{1}$
}

\begin{abstract}
Introduction
During the period 1453-1467 the fifteenth-century Greek émigré and humanist George of Trebizond wrote to the Turkish sultan, Mehmed II the Conqueror, three treatises and three letters in which he tried not only to formulate methods and principles of peaceful dialogue between Muslims and Christians, but also to describe his eschatological views. ${ }^{2}$ Modern scholars place great emphasis on the atypical concept of George of inter-confessional dialogue to such an extent that they fail to make any mention of close connection between the apocalyptic concept of George and his attitudes toward Islam. ${ }^{3}$
\end{abstract}

(1) Some ideas of this paper were discussed at the International Congress of Byzantine Studies (London, 2006). I am grateful to Dr. John Monfasani, Dr. Basil Lourie, Dr. Antonio Rigo and Dr. Rustam Shukurov for their comments and suggestions.

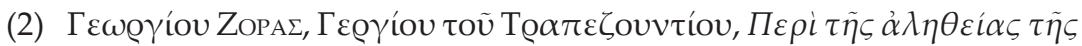

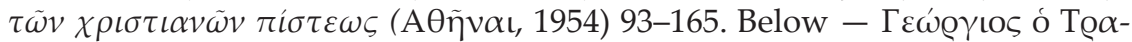
$\pi \varepsilon \zeta o u ́ v \tau ı$ s 1954; J. Monfasani, Collectanea Trapezuntiana. Texts, Documents and Bibliographies of George of Trebizond (New York, 1984). Below - CTr; J. MoN-

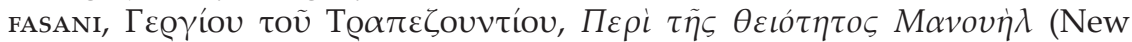

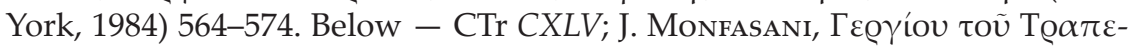

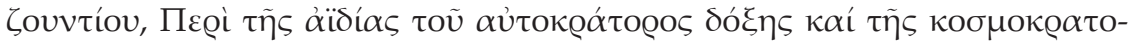

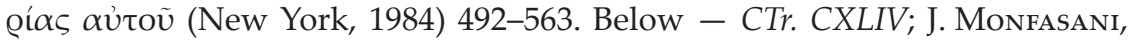
Georgius Trapezuntius, Epistola ad Mahomatem (New York, 1984) 281-284. Below - CTr. CXLIV; Edition of two Latin letters of George: A. MerCATI, Le due lettere di Giorgio da Trebisonda a Maometto II, OCP 9 (1943) 94-95; All quota-

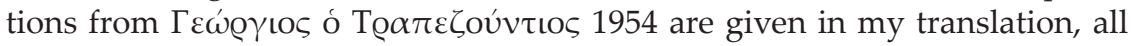
quotations from Collectanea Trapezuntiana - in J. Monfasani's translation.

(3) M. Balivet, Deux partisans de la fusion religieuse des chrétienne et de Musulmans au XVe siècle: le turc Bedreddin de Samavna et le Grec George de Trebizond, Byzantina 10 (1980) 363-396; M. BAlivet, Pour une concord islamochrétirnne. Démarches byzantines et latines à la fin du Moyen-Âge (de Nicolas de 
Besides, if the eschatological views of George's contemporary Gennadius Scholarius are well known to historians of Byzantine eschatology, there is no detailed information about the apocalyptic views of George of Trebizond. ${ }^{4}$ Nevertheless they deserve to be discussed.

J. Monfasani has suggested that he felt himself to be prophet. In his book devoted to George he writes: "Was George of Trebizond, rhetorician, curial official, and translator, a prophet besides? The answer is that he was a prophet most of all. Unless we accept this judgment not only do the most of his non-technical works make no sense, but also his later life will appear as one fit of madness." ${ }^{5}$ We need to remind ourselves that George predicted both the occurrences of the every-day world (using astrology $\mathrm{y}^{6}$ ) and the future of mankind (using Holy Scripture, apocalyptic writings and his own prophetic insight).

Apparently George was sure of his ability to predict the future. In his letter of 1469 to cardinal Bessarion, George confessed that by the divine aid he had grasped the mystery of the Last Days. ${ }^{7}$ He regarded himself as an outstanding interpreter of apocalyptic writings of the past. George wrote to Mehmed the Conqueror: "Observe therefore, most high and wise autocrat, if these things accord not only with what our prophets have foretold (as I myself well know, having studied them more than anyone else, I who take second place to no one in natural talent, in perfection of knowledge and devotion towards Your Greatness), but also with what has been written by many wise

Cues à George de Trébizonde) (Roma, 1997). A. Th. Khoury, George de Trébizonde et l'union islamo-chrétienne (Louvain, 1971); P. BADÉNAs. Corrientes conciliatoras de intelectuales griegos en la corte del Gran Turco, in: A. А. Чекалова (ред.), Мир Александра Каждана. К 80-летию со дня рождения (СанктПетербург, 2003) 273-280.

(4) C. J. Turner, Pages from Late Byzantine Philosophy of History, BZ 57 (1964) 346-373; C. J. Turner, An Oracular Interpretation Attributed to Genna-

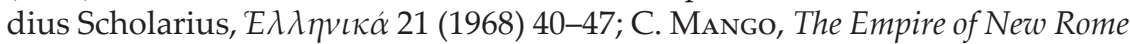
(London, 1980) 213; P. Magdalino, The year 1000 in Byzantium, The Medieval Mediterranean 45 (2003) 234-271.

(5) J. Monfasani, George of Trebizond: A Biography and a Study of his Rhetoric and Logic (Leiden, 1976) 86.

(6) George of Trebizond translated ps.-Ptolemy's Hundred Sayings in astrology (Centiloquium) and Ptolemy's Almagest and wrote commentaries on them. He was renowned as a mighty astrologer and mathematician. MonFaSANI, George of Trebizond..., 149.

(7) CTr. XXXVI. 179. 
students of Mohammedanism." ${ }^{8}$ This passage is remarkable for two reasons. First, George was sure that he had studied the old prophetic writings "more than anyone else", second, he studied both the Latin and Muslim prophecies. ${ }^{9}$

George of Trebizond believed in his prophetic talent to such an extent, that he wrote to the Pope Nicholas V: "There is no one, I believe, Most Blessed Father, who has studied the book and the prophecy of the Abbot Ioachim ${ }^{10}$ more than I. I had it with me in Venice when I was living there and I worked hard to understand everything that happened to the popes of my times." 11

In the sources which have been quoted we have seen that studying apocalyptic writings and creating eschatological predictions were George's labors of love. George felt himself to be prophet of doom and last events. In fact the treatises of the philosopher from Crete, which he wrote for Mehmed the Conqueror, confirmed this suggestion with good reason. The treatise On the divinity of Manuel as well as the treatise On the eternal glory of autocrat and his world-dominion demonstrate his original eschatological concept.

It's noteworthy to mention here that George also wrote in Latin a work On awesome events. ${ }^{12}$ This work was lost but it must have been of considerable length since George quoted from the $51^{\text {st }}$ chapter of Book II of this treatise. ${ }^{13}$ It is a pity that this work has not survived because other works of George don't provide us with exhaustive information

(8) CTr. CXLIV. 12. 530-531.

(9) On the relationship between the Byzantine and Turkish prophesies of the end of the world, see: M. BaLIvet, Byzantins et Ottomans: relations, interaction, succession (Istanbul, 1999) 181-195.

(10) George means the Papalista or Liber de pontificalibus, which was attributed to Ioachim of Flora. This book was a conflation of two different fourteenth century forgeries. The Papalista was considered to be the holder of the secrets of the destiny of the Roman Pontiffs. M. Reeves, The Influence of Prophecy in the Middle Ages (Oxford, 1969) 193-194, esp. 214; M. W. BцоomFIELD, Joachim of Flora: a Critical Survey of his Canon, Teachings, Sources, Biography and Influence, Traditio 13 (1957) 249-311; C. Mango, The Legend of Leo the Wise, Зборник Радова Византинолошки Институт 6 (1960) 59-93; Monfasani, George of Trebizond..., 86-87.

(11) CTr. LXXXVII. 288; Monfasani, George of Trebizond..., 85.

(12) CTr. CXLV. 4. 572.

(13) CTr. CXLV. 4.572 
of his apocalyptic vision. Thus his eschatological views are in need of reconstruction and interpretation.

In fact the predictions of George which are preserved are full of enigmas. Why did he think that Mehmed II would be the last Christian emperor? Why did George want to rename Mehmed II as Manuel? Did he identify the foul eschatological people Gog and Magog with the Turks? Did he identify the Turks with the Ismaelites of Pseudo-Methodius, that is with descendants of biblical Ishmael who were mentioned for the first time as eschatological people by archbishop of Patara? The answers to these questions give us an opportunity to understand the eschatological concept of George of Trebizond.

This paper interprets the treatises and letters of George of Trebizond which he addressed to Mehmed II the Conqueror. It analyses the traditional and new elements of his eschatological concept and some strange and even enigmatic passages of George's apocalyptic writings. The main aim of the paper is to demonstrate a close connection between the atypical views of George on Islam and his eschatological theory.

\section{A Problem of Islam and Eshatology}

It's impossible to understand what George thought about Islam without studying his eschatological ideas. R. Landes came to the conclusion that for all its ephemeral volatility, its protean qualities, its documentary disguises, the phenomenon of apocalyptic expectations and chiliastic enthusiasm belongs within the purview of the millennial generation. Otherwise we fail to appreciate the hearts and minds of people who lived, not in our Middle Ages, but in their Last Age. ${ }^{14}$ Indeed, I would suggest that George of Trebizond belonged to the millennial generation and more than anyone else in his epoch lived not in the fifteenth century but in his Last Age. It is in this context that one should approach an analysis of the eschatological views of George of Trebizond and their connections with his views on Islam.

In the fifteenth century, contacts between West and East became wider. Christian philosophers were forced by Turkish expansion to see the problem of Islam in a different light. George of Trebizond in his works tried to rethink the problem of dialogue with Muslims anew. He tried to find new ways of communicating with Muslims.

(14) R. LANDEs, The Fear of an Apocalyptic Year 1000: Augustinian Historiography, Medieval and Modern, Speculum 75 (2000) 145; Magdalino, The Year $1000 \ldots, 235$. 
He came to the conclusion that it was impossible to resolve the problem of Turkish expansion by using violence. He condemned both Christians and Muslims for crusade and jihad. ${ }^{15}$ George wrote that reason was more useful than a sword for the emperor who wanted to unite mankind in one faith. ${ }^{16} \mathrm{He}$ also condemned Christian and Muslim wise men for boasting and vanity. ${ }^{17}$

George of Trebizond was the first Byzantine and Italian writer who set out to understand why the dialogue between Christians and Muslims had not been effective. He thought that Christians must have known more about Islam and Muslims also must have tried to know more about Christian dogmas. ${ }^{18}$ George came to the conclusion that it had been the mutual ignorance (and especially ignorance in the field of languages) and use of violence that prevented an effective dialogue between Christians and Muslims. ${ }^{19}$

The Byzantine emperor Manuel II Palaeologos in his Dialogue with a Persian also complained that Muslims were not good at Greek and didn't understand him properly (especially when he were talking about sublime theological things) so he had to tell them the same thing two or three times. ${ }^{20}$ But he didn't care about the fact that Byzantine did not know Arabian and Turkish languages. More than that Manuel II Palaeologos wrote that the Turkish language was the language of barbarians. $^{21}$

On the contrary George of Trebizond thought that Christians and Muslims were both in need of knowledge of languages of each other. He wrote: "Disagreement was increased by the ignorance. Christians and Muslims couldn't talk to each other on account of an ignorance of languages."22 George even praised the Turkish language for its beauty. ${ }^{23}$

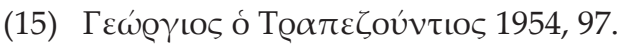

(16) Ibid.

(17) Ibid.

(18) Ibid., 98-99.

(19) Ibid.

(20) K. Förstel, Manuel II Palaiologos, Dialoge mit einem Muslim, t. I (Altenberg: Oros Verlag, 1993) 10.

(21) Ibid.

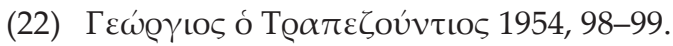

(23) Ibid, 94. 
It's hard to say if George knew the Arabian and Turkish languages or not. It is more important for us that he recognized the necessity of learning Arabian and Turkish languages for Christians. He also supposed that Christians and Muslims did not understand each other because of swear words. He wrote that swear words "kindled the fire of wrath, incited a great hatred and divided people." ${ }^{24}$

Did George of Trebizond think that these obstacles could be broken down? Without a doubt, he did. First of all he advised Mehmed II to talk about the Christian faith and to study Christian dogmas. ${ }^{25}$ After that George wanted the Turkish sultan to order to arrange frequent meetings in which wise Christians and wise Muslims should talk and search for the truth. ${ }^{26}$ George insisted that they were not to try to prove their own point of view but they were to "find the truth for the sake of love." ${ }^{27}$ The same idea of peaceful conference ("contraferentia") between Christians and Muslims as a method for breaking down Islam-Christian antagonism was created by a George's contemporary Spain cardinal John of Segovia. ${ }^{28}$

The dialogue between Christians and Muslims has lasted since the seventh century. ${ }^{29}$ But George of Trebizond was the first who tried to analyse the dialogue and to produce some exceptional reflections about it. In my opinion, his interpretation of Islam was quite atypical. George rejected almost all usual and widespread Christian's arguments against Islam. In his letters and treatises to Mehmed II he didn't criticise the prophet Muhammad, and the Koran as other Byzantine and Western writers did.

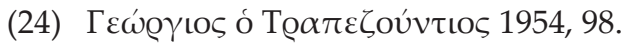

(25) Ibid., 96.

(26) Ibid.,113.

(27) Ibid.

(28) D. Cabanelas, Juan de Segovia y el problema islamico (Madrid, 1952) 343-349; R. Schwoebel, The Shadow of the Crescent: the Renaissance Image of the Turk (1453-1517) (New York, 1967) 222-225; R. W. Southern, Western Views of Islam in Middle Ages (Cambridge, 1962) 86-92.

(29) On the history of Byzantine and Western polemic against Islam see: A. Th. Khoury, Les théologiens byzantins et l'islam. I. Textes et auteures (VIIIXIII ${ }^{\text {s.) }}$ (Paris, 1969); A. Th. KHoury, Apologétique byzantine contre l'Islam (VIIIXIII s.) (Altenberg, 1982); A. Th. Khoury, Polémique byzantine contre l'Islam (Leiden, 1972); J. Meyendorff, Byzantine Views of Islam // DOP 18 (1964) 113-132; Southern, Western Views of Islam...; J. Tolan, Saracens. Islam in the Medieval European Imagination (New York, 2001). 
George of Trebizond reduced all the differences between Islam and Christianity to the three points. He supposed that the other differences as customs and way of life were not extremely important in this context. The philosopher from Crete wrote: "So if one house which consists of a wife and a husband, and of many sons and daughters, and of many sons-in-law and daughters-in-law can not agree to have one way of life, it will be, as I think, full to consider that the whole world might follow the one rule of life." ${ }^{30}$ It's noteworthy to mention here that this idea of George was a great novelty for the time, because for medieval polemists with Islam the criticism of the Muslim ethics and the customs and rituals of Muslims were as important as the criticism of Muslim dogmas.

As for the more important differences between Christians and Muslims from the viewpoint of George of Trebizond - the first was that Muslims had thought that Christians believed in three gods. ${ }^{31}$ The second was that Christians believed that Jesus Christ is the son of God and is God Himself. ${ }^{32}$ The third was that Jesus Christ died and rose from the dead and lives forever as the true God. ${ }^{33}$

Then George demonstrated that these differences were just imaginary. ${ }^{34}$ He wrote: "So, is there any difference between us, Christians, and you, Muslims? It seems to me, there is not. If there is the difference, it is only the difference in words. But wise men do not regard this as the difference. Because there are a lot of languages, a lot of peculiarities and methods of a speech. And each nation speaks according to the customs of his own dialect." ${ }^{35}$ He supposed that the dogmas of Islam and the Koran itself proved the truth of the Christian faith. ${ }^{36}$

In fact George of Trebizond declared an internal unity of Islam and Christianity. German cardinal Nicolas of Cusa went even further and declared a unity of all religions. ${ }^{37}$ In his treatise the On the peace of faith he tried to prove the principle "una religio in rituum varietate" (the one

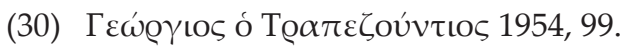

(31) Ibid.

(32) Ibid.

(33) Ibid.

(34) Ibid.

(35) Ibid., 112. 524-529.

(36) Ibid., 98-99.

(37) R. Klibansky, H. Bascour, Nicolai de Cusa, De pace fidei, Opera Omnia, t. LVIII (Hamburgi: Meiner, 1970). 
religion in the different rituals). This idea seems to be very close to the reflections of George of Trebizond, who maintains that if the one God exists then on the earth "the one faith, the one church, the one king-

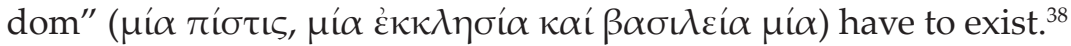

But does it mean that George of Trebizond regarded Islam as being identical to Christianity? The only scholar who tried to research this problem has been the remarkable specialist in Byzantine and Turkish Studies Michel Balivet. ${ }^{39}$ However, it is necessary to revise some of the results of his research.

M. Balivet regards the treatise On the truth of the Christian faith as the work about dogmatic unity of Christianity and Islam which outstripped for its audacity all the same attempts of the time. ${ }^{40} \mathrm{He}$ has also supposed that for George of Trebizond Islam was identical to Christianity. ${ }^{41}$ On the contrary, J. Monfasani maintains that George of Trebizond had hated Islam even more than he had admired Mehmed II the Conqueror. ${ }^{42}$ But let us turn back to the treatises of George themselves.

M. Balivet has based his research only on the treatise On the truth of the Christian Faith. But the other treatises of George as On the Divinity of Manuel and On the eternal glory of autocrat and his world-dominion merit detailed analysis as documents which clearly reveal the close relationship between the eschatological views of George and his attitudes toward Islam. These treatises also make clear some nebulous passages in On the truth of the Christian Faith.

In the treatise On the Divinity of Manuel George wrote that Antichrist was at the door and before the coming of Antichrist all the race would be converted to Christianity. ${ }^{43} \mathrm{He}$ added that "this divine and marvelous change" would take place through the agency of Mehmed II. ${ }^{44}$

Many Byzantine polemists with Islam were forced to recognize that the attempts to convert Muslims were condemned to fall through. Emperor Manuel Paleologos, one of the most brilliant polemists with Muslims in the fifteenth century, wrote with sorrow that Muslims did

(38) CTr. CXLIV / I. 5, 9.

(39) Balivet, Pour une concord islamo-chrétirnne...

(40) Ibid., 37.

(41) Balivet, Deux partisans de la fusion religieuse..., 383-385.

(42) Monfasani, George of Trebizond..., 199.

(43) CTr. CXLV. 570.

(44) CTr. CXLV. 570. 
not abandon their faith even though their arguments were broken down as false ones. He was convinced of the senselessness of the attempts to convert Muslims to Christianity. ${ }^{45}$

As for George of Trebizond he didn't stop thinking about the possibility of conversion of Muslims to Christianity. He did not regard the idea of converting Muslims as impossible because of his apocalyptic expectations. We need to remind ourselves that George of Trebizond had been living not in our Middle Ages but in his Last Age.

I would suggest that George's striving for a demonstration of the eternal unity of Islam and Christianity was a diplomatic tactic of George who had wanted to convert Mehmed II. The philosopher from Crete did not criticize the prophet Muhammad, the Koran and dogmas of Muslims because he had not wanted Mehmed II to get angry. George had wanted him to agree with his point of view. It was not a coincidence that in his letter to Pope Paul II, George explained that his excessive praise of Mehmed II had only been a technique for converting the Sultan to Christianity. ${ }^{46}$

As we have seen, George supposed that in letters and treatises to Muslims it had been unreasonable to criticize their faith. That is why it is not easy for scholars to understand what George thought about Islam.

Nevertheless in the treatise Comporationes philosophorum Aristotelis et Platonis ${ }^{47}$ George openly and severely criticized Islam and in the Oration on the death of martyr Andreas of $\mathrm{Hios}^{48}$ he condemned Christians who had been converted to Islam. It is important to note that these works were not intended for Muslims.

Even in one of the most peaceful of his writings On the truth of the Christian Faith we can find a hidden criticism of Islam. ${ }^{49}$ The treatise On the eternal glory contains deliberate and open criticism of Islam.

(45) Förstel, Manuel II Palaiologos, Dialoge mit einem Muslim..., 4.

(46) CTr. CII. 309; Monfasani, George of Trebizond..., 355-359, Appendix Nine.

(47) Georgius Trapezuntius, Comporationes philosophorum Aristotelis et Platonis a Georgio Trapezuntio viro clarissimo editae (Venetiis, 1523) (Repr. Frankfurt, 1965).

(48) Georgius Trapezuntius, Martyrologium Beati Andree de Chio, PG CLXI, 883B, 886D, 888D.

(49) On hidden critic of Islam in George's treatises see: $\Gamma \varepsilon \omega \hat{0} \gamma / \mathrm{tos}$ ó To $\alpha-$

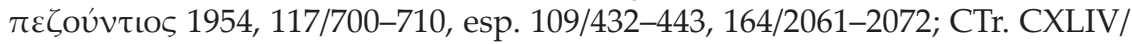
I.13. 
George wrote that according to Latin and Muslim prophecies after the capture of Constantinople the preaching of Islam would be collapsed. ${ }^{50}$

George predicted: "If the conqueror (that is Mehmed II) strives for the unity of the faith and of the Church, and if he demonstrates his zeal by deeds and not merely by words, than through him God will destroy Mohameth's creed and make the conqueror and his descendants lords of the whole world." ${ }^{51}$

In this passage we may see that the problem of Islam that George connected with the problem of universal last kingdom and the starting of the Last Days.

So, in the treatise George spoke about Islam with animosity. In my opinion, in the above mentioned passage, George had demonstrated his true attitude towards Islam. That is why it is impossible to agree with M. Balivet who has supposed that George demonstrated extremely tolerant attitude towards Islam. But George had broken his own principle about denunciation of the critic of Muslim dogmas. How can we interpret this fact?

To my mind the only surviving version of this treatise is a copy which has been made especially not for Mehmed II, but for the patron of George, cardinal Bessarion. It can explain why against of his principles concerning inter-confessional dialogue George openly criticized Islam. In the version for Christian reader George could more frankly talk about his attitudes towards Islam. That is why the treatise On the eternal glory is so different from the treatise On the truth of the Christian Faith.

Thus it can be concluded that George of Trebizond did not regarded Islam as being identical as Christianity. More than that it is impossible to say that he was extremely tolerant towards Islam. He regarded Islam as an important, but temporary stage in the apocalyptic drama. His main goal in the writings to Mehmed II was the conversion of the Turkish sultan to Christianity.

George of Trebizond was not the only man who had wanted to explain to Mehmed II the Conqueror the dogmas of Christian faith. The famous letter of Pope Pius II to the Turkish Sultan ${ }^{52}$ and the treatises

(50) CTr. CXLIV/I.12.

(51) Ibid.

(52) G. Toffanini (ed.), Pius II. Lettera a Maometto (Naples, 1953). English translation of the letter in another edition: A. R. BACA (ed.), Pius II. Epis- 
of the Greek Patriarch Gennade Scholarius ${ }^{53}$ were also the confessions of faith which had been written for Mehmed II. George Amiroutzes in his treatise The dialogue about the faith in Christ described his dialogues with Mehmed II about the religion of Christians. ${ }^{54}$ But George of Trebi-

tola ad Mahomatem (New York: Peter Lang, 1990); On the person of Pius see: C. M. Ady, Pius II, Eneas Silvius Piccolomini. The Humanist Pope (London, 1913); Ph. Levillain, Dictionnaire historique de la Papauté (Paris, 1994) 1323-1325; On Pius's letter to Mehmed II see: V. Poggi, Lettera non spedita di Pio II a Maometto II, Studi sull'Oriente Cristiano 7/2 (2003) 113-133; E. GARIN, Ritratti di umanisti (Firenze, 1967) 34; F. GAETA, Sulla lettera a Maometto II di Pio II, Bullettino dell'Istituto Storico Italiano per il medioevo e l'archivio muratoriano 77 (1965) 127-227; Southern, Western Views..., 99; Balivet, Pour une concorde islamo-chrétienne..., 3.

(53) L. Petit, X. A. Sidéridès, M. Jugie (eds.), Gennade Scholarius, CEuvres complètes de Gennade Sholarius, vol. IV (Paris, 1930) 434-475; On Gennadius Sholarius see: P. KonorTas, Les rapports juridiques et politiques entre le patriarcat orthodoxe de Constantinople et l'administration ottomane de 1453 à 1600 (d'après les documents grecs et ottomans), thèse dactylographiée, sous la direction de H. Ahrweiler (Paris: Paris I, 1985); M.-H. Blanchet, Georges Gennadios Scholarios (vers 1400 - vers 1472), premier patriarche de Constantinople sous la domination ottomane: personnage mythique, personnage réel, thèse dactylographiée, sous la dir. d'A. Ducellier (Université Toulouse II Le Mirail, 2005);

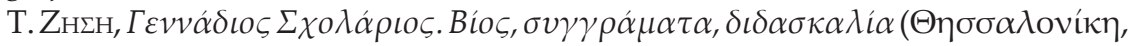
1988); C. J. Turner, The Career of George-Gennadius Scholarius, Byz 39, (1970) 420-455; Idem, Pages from Late Byzantine Philosophy of History, BZ 57 (1964) 346-373; IDEM, Another Anti-latin Work Attributed to Gennadius Scholarius, BZ 58 (1965) 337-347; IDEM, George-Gennadius Scholarius and the Union of Florence, JTS 18 (1967) 83-103; IDEM, An Oracular Interpretation At-

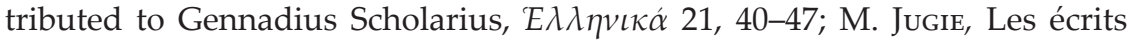
apologétiques de Gennadios Scholarios à musulmans, Byz 5 (1929) 295-314; A. Papadakis, Gennadius II and Mehmet the Conqueror, Byz 42 (1972) 88106.

(54) A. Argyriou, G. Lagarrigue, Georges Amiroutzès, Dialogue sur la foi au Christ tenu avec le sultan des Turcs, Byzantinische Forschungen 9 (1987) 29-221; J. Monfasani, “Lost" Final Part of Georges Amiroutzes' Dialogus de Fide in Christum and Zanobi Acciaiuoli Humanism and Creativity in the Renaissance, in: C. S. Ceienza, K. Couwens (eds.), Essays in Honor of Ronald G. Witt (Leiden-Boston, 2006); On George Amiroutzes see: С. КАрпов, Культура Трапезундской империи, в: Г. ЛитАврин (ред.), Культура Византии XIII- первая половина XV в. (Москва, 1991) 86-119; BaLIVEт, Pour une concorde islamo-chrétienne..., 26-27; M. BALIvet, Aristote au service du sultan! Ouverture aux turcs et aristotélisme chez quelques penseurs byzantins du quinzième siècle, dans: BALIVET, Byzantins et Ottomans..., 139-150; M. JugIE, La profession de foi de Georges Amiroutzès au concile de Florence, Échos d'Orient 36 (1937) 
zond was the only writer who had really believed in the possibility of the conversion of Mehmed to Christianity. The confidence of George had been based on his apocalyptic expectations.

\section{Apocalyptic Predictions of George of Trebizond and the Apocalypse of Pseudo-Methodius}

I would like now to consider in greater detail eschatological views of George of Trebizond. At the beginning of the treatise On the Divinity of Manuel George briefly declared his apocalyptic vision. His eschatological expectations are as follows:

1. First, that before the coming of Antichrist all races will of necessity be converted to God's truth, not by being pushed by us [Christians], but on their own initiative..$^{55}$

2. Second, that this divine and marvelous change will take place through the agency of some descendant of Ishmael.

3. Third, that now is the time. ${ }^{56}$

4. Fourth, that the present king of the Turks is the descendant of Ismael who will do these things. ${ }^{57}$

5. Fifth, that he will rule absolutely the whole world..$^{58}$

Thus George supposed that Mehmed II would be the last universal Christian Emperor who would establish the final universal Pax Christiana. He wrote: "From all the preceding, we must conclude that the king who descended from Ishmael has been divinely preordained to be the governor, minister and guardian of the final and true conversion of all the people to Christ and the reformation of Christians." ${ }^{59}$

Why did he think that Mehmed II should be the last Christian emperor? First of all because Mehmed had captured Constantinople. George noted: "I say, therefore, that in my opinion there has never been a man nor will there ever be one to whom God has granted a greater opportunity for sole dominion of the world than He has granted to Your Mightiness. Neither Cyrus nor Alexander nor Caesar nor

176-180; D. R. Reınsch, Byzantinisches Herrscherlob für den türkischen Sultan. Ein bisher unbekanntes Gedicht des Georgios Amirutzes auf Mehmed den Eroberer, Cupido Legum (Frankfurt a. M, 1985) 195-210.

(55) CTr. CXLV. 570.

(56) Ibid.

(57) Ibid.

(58) Ibid.

(59) CTr. CXLV. 572. 
Constantine were given as much. I arrived at this opinion immediately after I heard how God bestowed Constantinople on you." ${ }^{60}$

It was very important for George that, as he thought, Mehmed was the descendant of Ishmael and Abraham. George wrote: "It's obvious from his (Mehmed's) name that he is descended from Abraham through Ishmael." ${ }^{61}$ Therefore Mehmed should lead all the people to the Christian faith and through this he should fulfill God's obey to Abraham: "In Isaac you will have your seed called, but I will also make the son of your slave girl into a great people because he is your seed." 62 George was sure that "those who interpret Scripture accurately will not be able to doubt that now, at this moment, all the races of men will approach the cross of Christ through the agency of the descendant of Abraham who presently is king of both the Turks and the greatest part of the Christians." ${ }^{63}$

Did George realize that Mehmed II was not Arabian and therefore was not the descendant of Ishmael? Apparently he did not. George supposed that Turks, Muslims, Ishmaelites were synonymous: "For the Turks are called Ishmaelites from their king having taken this name. The race of Mohammedans is not one. Rather it is no race at all." ${ }^{64}$ I think that George means rather the spiritual affinity of all Muslims than ethnic relationship. The philosopher from Crete also emphasizes spiritual affinity of Christians and Muslims because of their memberships in the house of Abraham.

The idea that some descendant of Ishmael would become the last Christian Emperor was borrowed by George from the Apocalypse of Pseudo-Methodius. It's obvious that the Apocalypse of Pseudo-Methodius $^{65}$ (one of the most popular writings in Byzantium and in the West)

(60) CTr. CXLIV. I.2.

(61) CTr. CXLV. 571.

(62) Gen. 21: 12-13; CTr. CXLV. 571.

(63) CTr. CXLV. 572.

(64) CTr. CXLV. 571-572.

(65) Pseudo-Methodius was the third-century theologian and martyr, bishop of Olympus in Asia Minor, under whose name circulated the Apocalypse. E. Sackur, Sibyllinische Texte und Forshungen. Pseudo-Methodius. Adso und die Tiburtinische Sibylle (Halle, 1898; repr. Turin, 1963). Edition of Greek and Slavic versions of Apocalypsis: В. Истрин, Откровения Мефодия Патарского и апокрифические видения Даниила (Москва, 1987); New critic edition of the text (Greek and Latin versions): W. J. Aerts, G. A. Kortekaas, PseudoMethodius. Die Apokalypse (Lovanii, 1998). Syriac version of Apocalypse with 
had a great influence on the eschatological theory of George. ${ }^{66}$ George highly esteemed and cited Pseudo-Methodius. ${ }^{67}$ The Apocalypse of Pseudo-Methodius was written in the seventh century as a response to the Arab conquest of Byzantium. The treatises of George of Trebizond were a response on the fall to Constantinople and the Turkish conquest of Byzantium.

Even before the fall of Constantinople George was concerned about the appearance of people from Ethiopia, Ismaelites, which, according to Pseudo-Methodius, should start the apocalyptic cataclysm. In his letter of 1441 to the papal diplomat Ioannes de Dominicis he wrote that the appearance on 2 September 1441 at the Council of Florence of the monk Peter representing the Copts of Abyssinia is clear evidence that Antichrist is at the door. ${ }^{68}$

From his letters to Alfonso of Aragon (1442) and to the Holy Roman Emperor Frederick III (1452) we knew that George had considered the Turks to be the descendants of the "Ethiopians" (that is Ismaelities) who started the eschatological drama. ${ }^{69}$

Pseudo-Methodius supposed that the last emperor was the descendant of an Ethiopian princess. According to Pseudo-Methodius, the last Christian emperor will defeat Ismaelites and establish the last Christian kingdom, which will last until the incursions of the Gog and Magog and the revelation of Antichrist. Then the last Christian emperor, helpless against the Gog, Magog and Antichrist, will place his crown on the cross erected on the Golgotha. Raising his hands towards heaven he will see the cross ascend with the crown to the God. ${ }^{70}$ That is why in offering his crown to God he will fulfill the prophecy of the king David: "Ethiopia will stretch her hand out to God" (Ps. 67:32). From Genesis Pseudo-Methodius knew that Ishmael was born to Abraham of an Egyptian wife. According to the archbishop from Patara Ishmael was among descendant of the Ethiopian princess.

German translation: G. J. Reinink, Pseudo-Methodius, Die Apokalypse (Louvain, 1993).

(66) The question of the influence of Pseudo-Methodius on the writings of George was for the first time discussed by J. Monfasani: Monfasani, George of Trebizond..., 132-136.

(67) Monfasani, George of Trebizond..., 93.

(68) CTr. LXXIV. 262-263.

(69) CTr. CXXIX, CXXX. 422-431.

(70) SACKuR, Sibyllinische Texte..., 41. 
Mehmed II the Conqueror was identified by George of Trebizond with the descendant of Ishmael who must become the last Christian Emperor. In the treatise On the Divinity of Manuel George wrote: "That clearly, from many indications, the descendant of Ishmael who will do these things is the king of the Turks who became such just recently and is such now in the year from the incarnation 1467. For it is obvious from his name that he descended from Abraham through Ishmael. For the Turks are called Ishmaelites from their king having taken this name. ${ }^{\prime 71}$ From this passage we can see that George also identified Turks with Ishmaelites.

George was sure that Mehmed II's converting to Christianity would convert all the peoples and become the universal emperor: "Clearly then, Scripture predicted that the present descendant of Ishmael would be king over the whole world so that through him there would be converted to the Lord both the ends of the earth." 72

The eschatological scheme of George was not quite different from the predictions of the archbishop of Patara. To my mind George did not want to change radically the predictions of Pseudo-Mephodius. Of course George of Trebizond produced his own interpretations of Holy Scriptures and contemporary events, but he did it on the platform of Pseudo-Mephodius.

Reformation of Christians, from George's point of view, means punishment of Christians for their sins by Ishmaelites. George listed these sins: the schism of the Church, ${ }^{73}$ the win of the "Palamite heretics"74 and passion of the Roman Catholic priests for the philosophy of Plato. ${ }^{75}$

George supposed that the philosophy of Plato was extremely dangerous for the Christian Church. He wrote to Mehmed: "Then also occurred in Rome the apostasy from Christ to Plato at the instigation of Cardinal Bessarion, who is honored as pious by Pope Paul and by his own people because he lives his life according to Plato..." ${ }^{\prime 76}$ All of these sins according to George caused the capture of Constantinople. They also indicated that the end of the world was coming.
(71) CTr. CXLV. 4. 571.
(72) CTr. CXLV. 5. 573.
(73) Mercati, Le due lettere..., 94-95.
(74) Ibid.
(75) CTr. CXLV. 571.
(76) CTr. CXLV. 571. 
Why was George of Trebizond sure that the end of the world was at the door? He had confirmed his predictions by his own interpretations of Holy Scripture: the psalms of David, the Epistles of Apostle Paul, the Book of Genesis.

George expected the world to end in 1667 corresponding to the year 7170 of anno mundi chronology. ${ }^{77}$ It is not hard to see that this dating was the reflex to the symbol of the eight day (that is the eight millenium) when the cosmic week would come full circle. ${ }^{78}$

But George wrote that "now is the time" for last events. That is he thought he lived in the epoch when the last time began. He wrote: "The present moment is about two hundred years away from the end of Antichrist, as we showed in chapter 51 of Book 2 of the work written in Latin on awesome events." 79

According to P. Magdalino, in Byzantium dating the end took three main forms: 'blind dating', 'computus dating, and 'dating on the side. ${ }^{\prime 80}$ George of Trebizond used all of these forms of dating. 'Blind dating' was the reflex to natural phenomena or human events which were believed to herald the end of the world. For George such events, as we have already seen, were the capture of Constantinople and passion of the Roman Catholic priests for the philosophy of Plato. 'Computus dating' was the projection of numerically significant dates. In the case of George it was the symbol of the eight day (the eight millenium). 'Dating on the side' was the chronology projected by apocalyptic texts. In his predictions George used most of all apocalyptic text the Apocalypse of Pseudo-Methodius from Patara.

(77) CTr. CXLV.572.

(78) A. Sharf, The Eight Day of the Week, in: J. Chrysostomides (ed.), $K \alpha \theta \eta \gamma \dot{\tau} \tau \rho \iota \alpha$. Essays presented to Joan Hussey for her $80^{\text {th }}$ Birthday (London, 1988) 27-50; G. Podskalsky, Ruhestand oder Vollendung? Zur Symbolik des achten Tages in der griechisch-byzantinischen Theologie, in: G. Prinzing, D. Simon (hrsg.), Fest und Alltag in Byzanz (Munich, 1990) 157-66, 216-219; Magdalino, The Year $1000 \ldots, 236-238$.

(79) CTr. CXLV. 4. P.572.

(80) Magdalino, The Year 1000..., 239. 


\section{George of Trebizond and Mehmed II the Conqueror: the Imagery of the Turkish Sultan as a Prototype of the Messiah}

In the treatise On the Divinity of Manuel George had strongly recommended Mehmed II to change name and to take a new name - Manuel. ${ }^{81}$ As we have already said the predictions of George are full of enigmas. One of the most difficult of them is why George wanted to rename Mehmed II Manuel?

George of Trebizond believed that Mehmed II would be the Last Emperor. But the Last Emperor should be the Christian emperor of the Christian universal kingdom. The Turkish sultan was the Muslim. Thus George wanted Mehmed to convert to Christianity. But he did not suggest this openly. George veiled his suggestion: he wanted Mehmed to rename. ${ }^{82}$ He even chose the new name for the sultan: Manuel.

How did the philosopher from Crete argue the suggestion? His explanation was as follows: «For God altered the names of those whom he had chosen for the inauguration of great and wondrous deeds and for establishment and reformation either in some part as Abraham from Abram (Gen. 17:2), or while keeping only the first letter or syllable as Israel from Iacob (Gen. 35:9-10). ${ }^{83}$ Thus George is suggesting to Mehmed the new name (M $\alpha v$ où $\lambda$ ) has preserved the first syllable

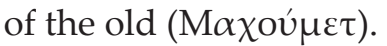

Obviously George regarded Turkish sultan as the Christian successor of Byzantine Empire. It's important to note that the name Manuel was the name of two Byzantine emperors: Manuel I Komninos (11431180) and Manuel Palaiologos (1391-1425).

Why did George of Trebizond choose the name Manuel? To my mind eschatological expectations of George were factors in the choice. The name Manuel is the Byzantine version of the Jewish Immanuel. In the New Testament the famous passage from the book of the prophet Isaia is quoted: "Behold, a virgin shall conceive, and bear a son, and shall call his name Immanuel." ${ }^{44}$ Then Evangelic explanation is followed: "Behold, a virgin shall be with child, and shall bring forth a son, and they shall call his name Emmanuel, which being interpreted

(81) CTr. CXLV. 570.

(82) CTr. CXLV. 570

(83) CTr. CXLV. 570

(84) Math. 1:23. Is. 7:14. 
is, God with us." ${ }^{85}$ I suppose that suggesting this name to Mehmed, George regarded the Turkish Sultan as the imagery and the symbol of the Messiah. As George expected the beginning of the Last Days he thought that the appearance of the last Emperor Manuel should be the prelude of the Epiphany. He promised Mehmed II that he would become an emperor of the whole world and heavens. ${ }^{86}$

George supposed that he had managed to understand God's idea about the Turkish sultan. According to the philosopher from Crete, not he wanted to change the name of Mehmed, but God Himself wanted to do so: "We should say why we name Manuel one who is not so named. We therefore declared that, in accordance with Holy Writ, we think it necessary that the future king of the world should not be called by his presently used name, but by the name with which he is about to be divinely graced." ${ }^{87}$ Apparently he hinted at the passage from the New Testament which explained the meaning of the name "Emmanuel" (Math. 1:23).

My interpretation of the new name which George had offered to Mehmed II was also confirmed by the expression "king of kings and lord of lords" which George of Trebizond used very often when he addressed to the sultan. ${ }^{88}$ The expression "king of kings and lord of lords" is taken from St. Paul Epistle (1 Tim. 6:15) and from The Book of Revelation (17:14, 19:6). In both cases the expression refers to the future Epiphany of Christ. ${ }^{89}$ This traditional Byzantine formula was often used in the imperial coinage as an official statement of the doctrine of symbasileia (that is the faith over which Christ co-reigns with a Byzantine emperor).

(85) Math. 1:23.

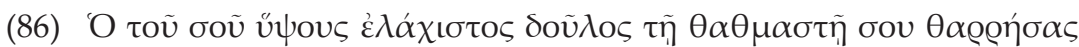

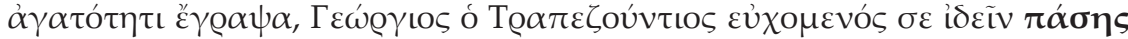

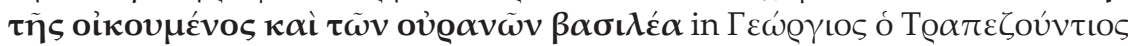
1954. 165/2073-2076.

(87) CTr. CXLV. 570.

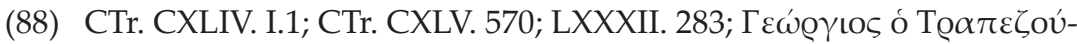
vтเоऽ 1954, 93.

(89) P. Magdalino fairly supposes that the apocalyptic connotations of the biblical quotation have been ignored by modern scholars, but they would not have been lost of Byzantine authors, for example, of the author of the Apocalypse of Pseudo-Methodius: Magdalino, The Year 1000..., 253. To my mind George of Trebizond used this expression in its apocalyptic meaning. 
Besides this, when George promised to Mehmed the world dominion he mentioned the wild ox: "It is clear that he who will set these things aright by the power of Christ, "the wild ox", will rule absolutely the whole world." 90 This expression is taken from David's Psalm (Ps. 21:21, 28:6, 21:28) also referring to the Epiphany of Christ.

Messianic character of the figure of the Last Roman Emperor was not an unusual thing for Byzantine apocalyptic literature because of influence of Jewish eschatology. It becomes especially clear from a small eschatological treatise The true emperor ( $\mathrm{O} \alpha \hat{\alpha} \lambda \theta$ เvòs $\beta \alpha \sigma \iota \lambda \varepsilon u ́ s) .{ }^{91}$ I think that this treatise had an influence on George of Trebizond. The manuscript of the treatise is dated of the sixteenth century, but according to a scribal note it was copied of the twelfth century at the latest. The treatise is a compilation of different Jewish and early Christian apocalyptic texts on the messianic ruler. It discussed the time when the true emperor will be revealed ${ }^{92}$ and physical characteristic as well as moral and mental qualities of the messianic ruler. ${ }^{93}$ An anonymous author called the Last Emperor the Anointed (o $\eta \lambda \varepsilon ц \mu \mu \varepsilon \dot{v o \varsigma}),{ }^{94}$ the

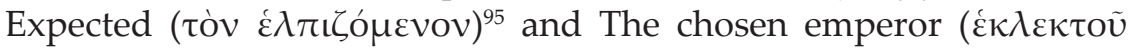
$\beta \alpha \sigma \iota \lambda \varepsilon \dot{v} \varsigma) .{ }^{96}$ Nevertheless the author of the treatise didn't mention a name of the Last Emperor. Thus George of Trebizond developing an idea of the last Christian emperor followed Byzantine apocalyptic tradition. ${ }^{97}$ It must be noted that nobody among George's contemporaries regarded the Turkish Sultan as the prototype of the Messiah.

$$
* * *
$$

(90) CTr. CXLV. 573. D. Nicol stated that according to the legend of immortal emperor the awaking of the sleeping emperor would be heralded by the bellowing of an ox. D. M. Nicol, The Immortal Emperor. The Life and Legend of Constantine Palaiologos, Last Emperor of the Romans (Cambridge, 1994) 104.

(91) This treatise is also known as Cento on the true emperor. See $O \dot{\alpha} \lambda \eta \theta \iota v \dot{~} \varsigma$ $\beta \alpha \sigma \iota \lambda \varepsilon \dot{v} \varsigma$, PG 107, 1141-1150. On the treatise see: P. J. AleXander, The Byzantine Apocalyptical Tradition (Berkeley, 1985) 130-136.

(92) PG 107, 1141.

(93) Ibid, 1141, 1. $36-1145 B, 1.3$.

(94) Ibid, 1141, 1. 19; 1144B, 1. 5, 15; 1148A, 1. 2.

(95) Ibid, 1148A, 1. 12.

(96) Ibid, 1141, 1. 4.

(97) On the expectation of a Last Roman (Byzantine) Emperor as one of the main themes in Byzantine apocalyptic tradition see: Alexander, The Byzantine Apocalyptical Tradition..., 152-184. 
George believed in his prophetic talent to such an extent that he was ready to risk his life telling Mehmed II that he would be the emperor of the whole world. George wrote his treatise On the Divinity of Manuel in 1467 when he was an old and ill man. A man who had been imprisoned because of his letters to the Turkish sultan. But even suffering in prison could not shake his conviction in his ability to predict the future.

George of Trebizond was not well informed in the field of Islam and of the Koran. His knowledge in this field was fragmentary and chaotic. He was also not a remarkable polemist with Islam. However he produced some atypical ideas about religious dialogue between Christians and Muslims. In this sense George of Trebizond was a remarkable person because he was able to get over the narrowness of medieval picture of the universe. He didn't regard Muslims as barbarians and enemies of Christ. He had declared a necessity of studying Islam in order to make inter-confessional dialogue more effective. But I think that it would be a mistake to mix George's principles of the dialogue with Muslims and his real attitudes toward Islam.

Thus George suggested a new method of converting Muslims to Christianity. As we have already said the main aim of his letters and treatises to Mehmed was to convert the Turkish sultan. His enthusiasm about the possibility of converting Muslims was apocalyptic enthusiasm of the man who thought that he could predict the future of mankind. The man who was very much impressed by the Apocalypse of the archbishop of Patara and who creatively developed the ideas of Pseudo-Methodious.

\section{SUMMARY}

This paper deals with the treatises and letters of George of Trebizond addressed to Mehmed II the Conqueror. The author analyses the traditional and new elements of George's eschatological concept and some strange and even enigmatic passages of George's apocalyptic writings. The main aim of the paper is to demonstrate a close connexion between George's atypical views on Islam and his eschatological theory. The author suggests that the degree of religious tolerance expressed by George of Trebizond has been somewhat exaggerated by modern researchers, in particular by M. Balivet. The paper proves that it is impossible to conclude that George of Trebizond was ready to equate Islam and Christianity. It also shows that George suggested a new method of converting Muslims to Christianity, which was based on his apocalyptic concept. 